Indonesian Journal of Medicine (2018), 162-167

https://doi.org/10.26911/theijmed.2018.03.03.06

\title{
The Effect of Colchicine Administration on HsCRP Level and Mean Platelet Volume in Patients with Miocard Acute Infark
}

\author{
Trisulo Wasyanto'), Ahmad Yasa'1), Bhisma Murti²) \\ 1)Department Cardiology and Vascular Medicine, Faculty of Medicine, \\ Universitas Sebelas Maret/Dr.Moewardi General Hospital, Surakarta \\ ${ }^{2)}$ Masters Program in Public Health, Universitas Sebelas Maret
}

\begin{abstract}
Background: Patients with coronary heart disease (CHD) who have received standard therapy to the fullest, are still at risk for further cardiovascular events. This is likely because the standard therapy fails to inhibit some inflammatory pathways and platelet aggregation which implies the disease. This study aimed to determine the effect of colchicine on reducing levels of high sensitive c-reactive protein (HsCRP) and mean platelet volume (MPV) in patients with Acute Myocardial Infarction (IMA) in the Intensive Cardiovascular Unit (ICVCU) Dr. Moewardi Hospital, Surakarta.

Subjects and Method: Experimental study was conducted with pre and post design. The study was conducted from November 1 to December 31, 2016. A sample of 32 patients with Acute Myocardial Infarction was divided into two groups. The control group was given a placebo and the treatment group was given colchicine $0.5 \mathrm{mg}$ orally for 5 days. Statistical analysis was done using two mean different tests with dependent t-test or Mann-Whitney and two mean analysis paired using independent $t$ test or Wilcoxon.

Results: The HsCRP delta level in colchicine group (mean $=3.82 ; \mathrm{SD}=2.20$ ) was higher than control group (mean $=0.57 ; \mathrm{SD}=3.12)$ and it was statistically significant $(\mathrm{p}<0.001)$. The delta MPV levels in colchicine group (mean $=2.01$; $\mathrm{SD}=1.16)$ were higher than control group (mean $=$ $0.64 ; \mathrm{SD}=0.83$ ) and it was statistically significant $(\mathrm{p}=0.001)$.

Conclusions: The administration of $0.5 \mathrm{mg}$ colchicine by oral for 5 days was associated with levels of HsCRP and MPV among IMA patients.
\end{abstract}

Keywords: Colchicine, HsCRP, MPV, Acute Myocardial Infarction

\section{Correspondence:}

Trisulo Wasyanto. Department of Cardiology and Vascular Medicine, Faculty of Medicine, Universitas Sebelas Maret. Jl. Ir. Sutami 36A, Surakarta57126, Central Java, Indonesia. Email: trisulo.wasyanto@gmail.com

\section{BACKGROUND}

Coronary heart disease (CHD) according to the 2013 Indonesian Ministry of Health's Basic Health Research causes the highest mortality in Indonesian population (Indonesian Agency for Health Research and Development Ministry of Health, 2013). CHD patients who have received standard therapy to the fullest, are still at risk for further cardiovascular events, this is likely due to standard therapy failing to inhibit some inflammatory pathways that implicate the disease (Nidorf et al., 2013). Acute coronary syndrome (SKA ) associated with a systemic inflammatory response in which acute plasma protein increases, including C-reactive protein (CRP). Increased plasma CRP levels are associated with worsening SKA output and risk stratification of death and heart failure (Orn et al., 2009). Sichiele et al. in 2009 concluded that in IMA patients, high CRP levels were an independent predictor of death for 30 days (Schiele et al., 2009).

Mean platelet volume (MPV) is the measurement most often used to assess 
platelet size. Larger volume platelets contain more prothrombotic material including thromboxane A2 and B2 thromboxane, Pselectin and more glycoprotein IIb / IIIa receptors (Bergoli et al., 2014). In patients with mediterranean fever who are treated with colchicine there is a decrease in MPV (Deftereos et al., 2013a).

Colchicine provides a therapeutic effect through interference with several stages of the inflammatory process (Deftereos et al., 2013 and Deftereos et al., 2014).

In 2004, the Food Drug Administration (FDA) approved colchicine for the treatment of Mediterranean fever and acute gout and prophylaxis of gout arthritis. Colchicine is currently also used as secondline therapy for the treatment of pericarditis (Deftereos, et al. 2013). A study conducted by Scehjerning et al. 2007 aimed to evaluate whether low-dose colchicine as an anti-inflammatory therapy can reduce HsCRP levels in stable CHD patients (Scehjerning et al., 2013). Cyclicin is known to inhibit neutrophil adhesion to vascular endothelium. In addition, it also increases the levels of cyclic adenosine monophosphate leukocyte, inhibits the production of interleukin-1 (IL-1) by activated neutrophils and inhibits tumor necrosis factor alpha (TNF- $\alpha$ ) receptors in macrophages and endothelial cells. Colchicine can inhibit activation of $\mathrm{NLRP}_{3}$ inflammasome protein complex which cleaves caspase-1 proteolysis and causes proinflammatory cytokines IL-1b and IL-18 (Terteltaub, 2009).

The aim of this study is to determine the effect of oral administration of colchicine $0.5 \mathrm{mg}$ for 5 days on decreasing levels of high sensitive CRP (HsCRP) and platelete volume (MPV) in IMA patients.

\section{SUBJECTS AND METHOD}

This was a randomized control trial study. A sample of 32 IMA patients aged 18 to 75 years at Dr. Moerwardi hospital, Surakarta, Central Java, from November 1 to December 31, 2016 was chosen by random sampling. The exclusion criteria were patients with cardiogenic shock or severe heart failure, Chronic Liver Disease, Infection, Malignancy, and previous Colchicine treatment. The sample was divided into 2 groups. The treatment group was given colchicine $0.5 \mathrm{mg}$ orally for 5 days. The control group was given a placebo.

Antecubial venous blood was taken to examine HsCRP and MPV, processing, storing blood samples and MPV and HsCRP examinations carried out by officers from Dr. MoewardiHospital Clinical Laboratory.

The data analysis was conducted using different mean tests. To find out the difference in mean between treatment groups and controls before and after treatment, an independent sample $t$ test was used if the data distribution was normal (if it is not normal, the Mann Whitney test is used).

This study has received permission from the Ethical Clearance Committee of the Dr. Moewardi Hospital Research Ethics Committee / Surakarta UNS FK.

\begin{tabular}{l}
\hline RESULTS \\
\hline There were no significant differences \\
between treatment and control groups on \\
variables: age, gender, diagnosis of STEMI \\
or NSTEMI, administration of strepto- \\
kinase, use of ACE inhibitors, use of Beta \\
Blockers, and risk factors for IMA such as \\
hypertension, diabetes, smoking, drinking \\
alcohol, and dyslipidemia and CKMB and \\
troponin I levels, IMA degrees according to \\
the KILLIP class.
\end{tabular}


Table 1. Characteristics of IMA patients

\begin{tabular}{lccc}
\hline \multicolumn{1}{c}{$\begin{array}{c}\text { Independent } \\
\text { variables }\end{array}$} & $\begin{array}{c}\text { Treatment } \\
\text { (n=16) }\end{array}$ & $\begin{array}{c}\text { Control } \\
\text { (n= 16) }\end{array}$ & p \\
\cline { 2 - 3 } Mean / Total (\%) & Mean/ Total (\%) & 0.178 \\
Age & 57.87 & 52.87 & \\
$\quad$ Male & $14(44)$ & $14(44)$ & \\
$\quad$ Female & $2(6)$ & $2(6)$ & \\
Diagnosis & & & 0.238 \\
$\quad$ STEMI & $10(31)$ & $13(41)$ & 1 \\
$\quad$ NSTEMI & $6(19)$ & $3(9)$ & 0.280 \\
Streptokinase & $6(19)$ & $6(19)$ & 1 \\
ACE Inhibitor & $11(34)$ & $8(25)$ & 1 \\
Beta Blocker & $15(47)$ & $15(47)$ & 0.723 \\
Statin & $16(50)$ & $16(50)$ & 0.669 \\
Hypertension & $8(25)$ & $7(22)$ & 0.238 \\
Diabetes & $3(9)$ & $4(13)$ & 1 \\
Smoking & $13(41)$ & $10(31)$ & 0.238 \\
Alcohol & $1(3)$ & $1(3)$ & \\
Dyslipidemia & $3(9)$ & $1(3)$ & 0.718 \\
KILLIP & $10(31)$ & $11(34)$ & 0.897 \\
$\quad 1$ & $6(19)$ & $5(16)$ & 0.138 \\
\hline 2 & 33.44 & 64.61 & \\
CKMB & 3.42 & 9.42 & \\
Troponin I & & & \\
\hline
\end{tabular}

The 2 mean difference test between HsCRP level $(\mathrm{p}=0.056)$ and MPV value ( $\mathrm{p}$ $=0.098$ ) between the control group and the treatment group before colchicine administration showed no significant differences (Table 2).

Table 2. Comparison of HsCRP and MPV levels before treatment

\begin{tabular}{lccccc}
\hline \multirow{2}{*}{$\begin{array}{c}\text { Independent } \\
\text { Variables }\end{array}$} & Treatment & Control & \multicolumn{2}{c}{ 2 Mean Difference Test } \\
\cline { 2 - 6 } & Mean \pm SD & Mean \pm SD & SE & p & CI 95\% \\
\hline HsCRP & $6.13 \pm 2.65$ & $4.78 \pm 3.45$ & 16.50 & 0.056 & 0.13 to 0.01 \\
MPV & $9.15 \pm 0.95$ & $8.63 \pm 0.95$ & 0.31 & 0.098 & -1.15 to 0.10 \\
\hline
\end{tabular}

After the administration of oral colchicine $0.5 \mathrm{mg}$ for 5 days, there were significant differences in HsCRP (delta HsCRP)

Table 3. Comparison of Delta-HsCRP

Groups

\begin{tabular}{cccccc}
\hline Variables & Treatment & Control & \multicolumn{2}{c}{ 2 Mean Difference Test } \\
\cline { 2 - 6 } & Mean \pm SD & Mean \pm SD & SE & p & CI 95\% \\
\hline Delta & $3.82 \pm 2.20$ & $0.57 \pm 3.12$ & 26.53 & $<0.001$ & 0.01 to 0.09 \\
$\begin{array}{c}\text { HsCRP } \\
\text { Delta } \\
\text { MPV }\end{array}$ & $-2.01 \pm 1.16$ & $0.64 \pm 0.83$ & 0.36 & 0.001 & 0.64 to 2.07 \\
\hline
\end{tabular}

Delta-HsCRP, the difference between HsCRP levels before and after colchicine.

Delta-MPV, the difference in MPV values before and after colchicine. 


\section{DISCUSSION}

The results of this study showed that there were significant differences in HsCRP levels after treatment (giving colchicine $0.5 \mathrm{mg}$ for 5 days) between the control group and the treatment group. There was a significant decrease in HsCRP (delta HsCRP) levels between the control group and the treatment group, whereas the HsCRP level before treatment there was no significant difference between the control group and Delta HsCRP treatment was the difference in HsCRP levels before treatment and after treatment. The results of this study indicated that the administration of colchicine can significantly reduce HsCRP levels in patients with acute myocardial infarction. Previous studies have only focused on giving colchicine to patients with stable coronary heart disease, no one has examined the effects of colchicine on the acute phase in IMA patients.

The results of this study were in accordance with Nidorf and Thomson (2007) which added colchicine to patients with stable coronary heart disease who had been given standard therapy, concluded that administration of colchicine can reduce HsCRP levels in patients with stable Coronary Heart Disease (Nidorf and Thompson, 2007) Nidorf et al. (2013), reported that giving colchicine by $0.5 \mathrm{mg}$ to standard therapy in patients with stable Coronary Heart Disease can provide secondary prevention, so that colchicine can reduce the risk of cardiovascular events such as the occurrence of IMA, sudden death and stroke in patients with stable Coronary Heart Disease (Nidorf et al., 2013). The results of this study were in line with previous studies which stated that colchicine can reduce HsCRP levels both in conditions of stable coronary heart disease and in the acute phase of acute myocardial infarction.
(Giannopoulos et al, 2015; Kaski, 2010; Nann, 2014; Molad, 2012).

The mechanism for decreasing HsCRP levels in colchicine was related to the effect of colchicine on suppressing caspase- 1 activity, the enzymatic component of the nucleotide-binding oligomerization domain (NOD-like receptor) receptor. The suppression of Caspase-1 blocked the conversion of pro-interleukin (IL) $-1 \mathrm{~b}$ to active IL-1b, resulting in a reduction in cytokines such as tumor necrosis factor-alpha (TNFa) and IL-6 (Slobodnick et al., 2015). IL-6 stimulated CRP production in the liver (Kumar and Cannon, 2009). The results of this study were in accordance with the theoretical concept of giving colchicine can suppress caspase 1 activity, there was a decrease in the level of IL-6 which ultimately caused a decrease in HsCRP levels.

The findings of this study also showed that there were differences on MPV values after treatment between the control group and the treatment group who got colchicine, in addition, there was a significant decrease (delta MPV) between the control group and the treatment group. Delta MPV was the difference in MPV value before treatment and after treatment. Previous study on the effect of colchicine on MPV was only in mediterranean fever patients, it was concluded that the administration of colchicine could reduce MPV in mediterranean fever patients (Defetereos et al., 2013).

This study was the first study to assess the effect of colchicine on decreasing MPV in patients with Acute Myocardial Infarction. This study was in accordance with the results of previous studies, which stated that the administration of colchicine can reduce MPV values in stable CHD patients (Yuri et al, 2011; Fox et al, 2013). MPV was associated with output in patients with acute myocardial infarction (Chu et al., 
2010). The greater the MPV indicated the more reactive of platelets and the less responsive to antiplatelet administration (Yuri et al,2011).

It was expected that by reducing MPV, it can cause external improvement in patients with acute myocar infarction. The mechanism of the influence of colchicine on decreasing MPV was associated with inhibition of IL-6 formation by colchicine (Slobodnick et al., 2015). IL-6 induced changes in megakaryocyte maturity resulting in an increase in platelet size that can be measured by MPV (Loo and Martin., 1999). This study was also in line with the theoretical concept of colchicine which can reduce the levels of IL- 6 which ultimately caused a decrease in MPV.

This study only focused on suppressing inflammation and the role of platelet function in preventing the occurrence of morbidity and mortality rates of IMA patients treated at Dr. Moewardi Hospital. Further study was needed from the effects of colchicine on clinical outcomes such as the occurrence of recurrent acute myocardial infarction, heart failure, or death during hospital treatment.

Based on the results of this study, it can be concluded that the administration of $0.5 \mathrm{mg}$ of Colchicine for 5 days can reduce HsCRP and MPV levels in patients with acute myocardial infarction. The results of this study were expected to provide therapeutic options for the management of IMA patients.

\section{REFERENCES}

Badan Penelitian dan Pengembangan Kesehatan Kementerian Kesehatan RI (2013). Riset Kesehatan Dasar 2013. Jakarta: Kementerian Kesehatan RI.

Bergoli L, Castanho E, Gonçalves S, Wainstein R, Piardi G, Araújo G, et al. (2014). Mean platelet volume as a predictor of major cardiovascular outcomes and final coronary flow in patients undergoing primary percutaneous coronary intervention. Revista Brasileira de Cardiologia Invasiva, 22: 240-4.

Chu S, Becker C,Berger P, Bhatt D, Eikelboom J, Konkle B, et al. (2010). Mean platelet volume as a predictor of cardiovascular risk: A systematic review and meta-analysis. Journal of Thrombosis and Haemostasis, 8: 148-56.

Dahlan S (2013). Besar sampel dan cara pengambilan sampel dalam penelitian kedokteran dan kesehatan, Jakarta, Salemba Medika.

Deftereos S, Giannopoulos G, Papoutsidakis N, Panagopoulou V, Kossyvakis C, Raisakis K, et al. (2013). Colchicine and the heart: Pushing the envelope. Journal of the American College of Cardiology, 62: 1817-25.

Deftereos S, Giannopoulos G,Papoutsidakis N, Bouras G, Raisakis K, Cleman W et al. (2014). Anti-inflammatory treatment with colchicine in stable chronic heart failure: A prospective, randomized study. Journal of the American College of Cardiology. 2: 131-7.

Fox A, White D, Gersh B, Jessica J, Opie H (2013). Antithrombotic agents: Platelet inhibitors, acute anticoagulants, fibrinolytics, and chronic anticoagulants. In: Opie LH. Drugs for the heart. Philadelphia: Elsevier. Seven Edition. 332-40.

Giannopoulos G, Angelidis C, Kouritas K, Dedeilias P, Filippatos G, Cleman M et al. (2015). Usefulness of colchicine to reduce perioperative myocardial damage in patients who underwent onpump coronary artery bypass grafting. The American journal of cardiology, 115: 1376-81. 
Kaski JC (2010). C-reactive protein improves risk prediction in patients with acute coronary syndrome, or does it?. European heart journal, 31: 290-7.

Kumar A, Cannon CP (2009). Acute coronarysyndromes: Diagnosis and management. Mayo Clinic Proceedings, 84: 917-38.

Libby P, Ridker P, Maseri A, Paul M (2002). Inflammation and atherosclerosis. Circulation, 105: 1135-43.

Loo B, Martin J (1999). A role for changes inplatelet production in the cause of acute coronary syndromes. Journal of the American College of Cardiology Arteriosclerosis, 19: 672-9.

Mann DL (2014). Colchicine and the failing heart: A "finer" anti-inflammatory agent?. Journal of the American College of Cardiology, 2: 138-40.

Mendis S, Thygesen K, Kuulasmaa K, Giampaoli S, Maho M, Blackett K, et al. (2011).World Health Organization definition of myocardial infarction: 2008-09 revision. International Journal of Epidemiology, 40: 139-46.

Molad Y (2002). Update on colchicine and its mechanism of action. Current rheumatology reports. 4: 252-6.

Nidorf M, Thompson PL (2007). Effect of colchicine (0.5 mg twice daily) on high-sensitivity c-reactive protein independen of aspirin and atorvastatin in patients with stable coronary artery disease. The American journal of cardiology, 99: 805-7.
Nidorf M, Eikelboom J, Budgeon, Thompson $P$ (2013). Low-dose colchicine for secondary prevention of cardiovascular disease. Journal of the American College of Cardiology. 61: 404-10.

Orn S, Manhenke C, Ueland T, Damås J, Mollnes T, Edvardsen T, et al. (2009). C-reactive protein, infarct size, microvascular obstruction, and left-ventricular remodelling following acute myocardial infarction. European heart journal. 30: 1180-6.

Slobodnick A, Shah B, Pillinger M, Krasnokutky S (2015). Colchicine: Old and new. The American journal of medicine, 128: 461-70.

Schjerning O, Fosbøl L, Lindhardsen J, Andersson C, Folke F, Nielsen B, et al. (2013). Cause-specific cardiovascular risk associated with nonsteroidal antiinflammatory drugs among myocardial infarction patients-a nationwide study. PloS one. 8: e54309.

Schiele F, Nicolas M, Marie F, Romain C, Vincent D, Joanna D, et al. (2009). Creactive protein improves risk prediction in patients with acute coronary syndromes. European heart journal, 31: $290-7$.

Terkeltau RA (2009). Colchicine update: 2008. Seminars in arthritis and rheumatism,38: 411-9.

Yuri G, Ayvazyan L, Dimitri P, Mikhalidis A, Kitas G (2011). Mean platelet volume: A link between thrombosis and inflammation? Current pharmaceutical design, 17: 47-58. 